\title{
Land use Change Detection of Khana Local Government Area of Rivers State Using Remote Sensing and GIS
}

\author{
Needam B. G ${ }^{1}$, Wokocha, C. $C^{2}$, and Kamalu O. J $\mathbf{J}^{3}$ \\ ${ }^{1-2-3}$ Department of Crop and Soil Science, \\ University of Port Harcourt, \\ PMB 5323 Port-Harcourt, \\ Rivers State, Nigeria
}

\begin{abstract}
This research involved the integration of remote sensing techniques with a Geographic Information System (GIS) framework to get information on the area under study using PC-based image processing and analysis. Landsat satellite imageries of Khana area was used and a Supervised Classification System (SCS) was adopted using ArcGIS 10.1 software. Selected bands (7,5 and 3) were processed, training sites were selected to represent land-use classes and image classification was carried out. A time change mapping and analysis was undertaken for the years 1987, 2000, and 2018. The area in square kilometers of each landuse type in each year was calculated and thereafter, the change was determined by subtracting the area of the same land-use type in 1987 from 2018. It was revealed that there was a high percentage of spatial expansion and reduction of some land-use types in the study area between these periods. There was a steady decline of about 77\% in the forested areas from 1987 all through 2000 to 2018 (-228km2). Cultivated land reduced by 38.46\% due to man's anthropogenic activities (-80km2) and this greatly affected food security in the study area. Water bodies also decreased all through that period in the study area (-2km2). The study area has been greatly affected by the extent of man's activities, which have violently shoved away and altered the hydrological pattern as well as creating micro reliefs and changing the traditional land use pattern of forestry and farmlands
\end{abstract}

Key words: Land-use, Change detection, Remote sensing.

\section{INTRODUCTION}

Agricultural land-use data are important for many of the regional to global activities including the validation of agricultural land evaluation; the preparation of perspective studies on agricultural production and food security; early warning for food security; natural disaster relief operations; farming systems studies; policy formulation. Thus, knowledge of current land use and land resources is needed for formulating changes leading to sustainable use of the resources [1]. Knowledge about land use and land cover has become increasingly important in any nation's plan to overcome the problems of haphazard, uncontrolled development, deteriorating environmental quality, loss of prime agricultural lands, destruction of important wetlands, and loss of fish and wildlife habitat [2].

Accounting for the changes in land use over time in any region is one way to take care of the pattern of resource consumption and to take effective steps for regional development in the wake of number of socioeconomic issues triggered by increase in population. A modern nation should prioritize the acquisition of adequate information of how its activities affect nature and the livelihood of its citizens. Land use is only one such activity. The importance of land use and land cover data can never be overemphasized. The information that this data brings to light could be used to equalize several tax assessments. These data can also be used for water-resource inventory, flood control, water-supply planning, and waste-water treatment by the State. Current comprehensive inventories of activities that are performed on public land as well as information about what the surrounding private lands are used for is pertinent to improve the management of such lands. In order to formulate proper and effective public policy and its evaluation, adequate understanding of these factors and its eventual influence on land use pattern is needed [3]. 
When an object is observed at different times in order to identify any difference in its state, the process is called change detection [4]. Change detection is an important process in monitoring and managing natural resources and urban development because it provides quantitative analysis of the spatial distribution of the population of interest. In the South-south ecological zone of Nigeria, Khana area of Rivers State, subsistence agriculture is mainly practiced despite the decline in area and quality of cultivable land. The study area has experienced these land use changes especially cultivation of natural lands which have led to possible negative effects associated with reduced cultivable lands and reduced fallow periods leading to declining agricultural productivity. Other factors which include population explosion and environmental factors have also led to the indiscriminate use of natural forest and under-utilization of current land use systems. Such human-induced land use changes have led to the deterioration of the properties of the soil which give rise to its degradation and decreased agricultural productivity.

Considering land use and Soil quality status being the major challenges for sustainable agricultural production and development [5], various land use types were assessed in different periods to show the spatial status of the land use systems in Khana area of Rivers State, thus showing the effect of land use changes over time. Understanding the spatial distribution of land use systems will not only help in increasing agricultural productivity but will aid in developing good agricultural policies to ensure optimum utilization of these land use systems. Also, future effects of land use changes can be estimated with the help of previous and current data generated. The objective of this study is to assess land-use and land-cover changes in the area over a 30year period (1987, 2000, and 2018) using remote sensing and GIS.

\section{MATERIALS AND METHODS}

The research was conducted in Khana local government area of Rivers State, situated approximately between Latitude $4^{0} 33^{\prime} 30^{\prime \prime}$ $\mathrm{N}$ to $4^{0} 49^{\prime} 22^{\prime \prime} \mathrm{N}$ and Longitude $7^{0} 19^{\prime} 11^{\prime \prime} \mathrm{E}$ to $7^{0} 31^{\prime} 09^{\prime \prime} \mathrm{E}$ (Fig. 1). Khana LGA is one of the four local governments areas in Ogoni, sharing boundaries with Oyigbo, Opobo-Nkoro, Akwa-Ibom, and Gokana in the North, South, East and West respectively. With a total area of about $575 \mathrm{~km}^{2}$, Khana is the largest local government in Ogoni covering approximately $56 \%$ of the total land area of Ogoni. The area consists of nearly level land with gentle and undulating slopes intersected by shallow valleys that carry water intermittently.

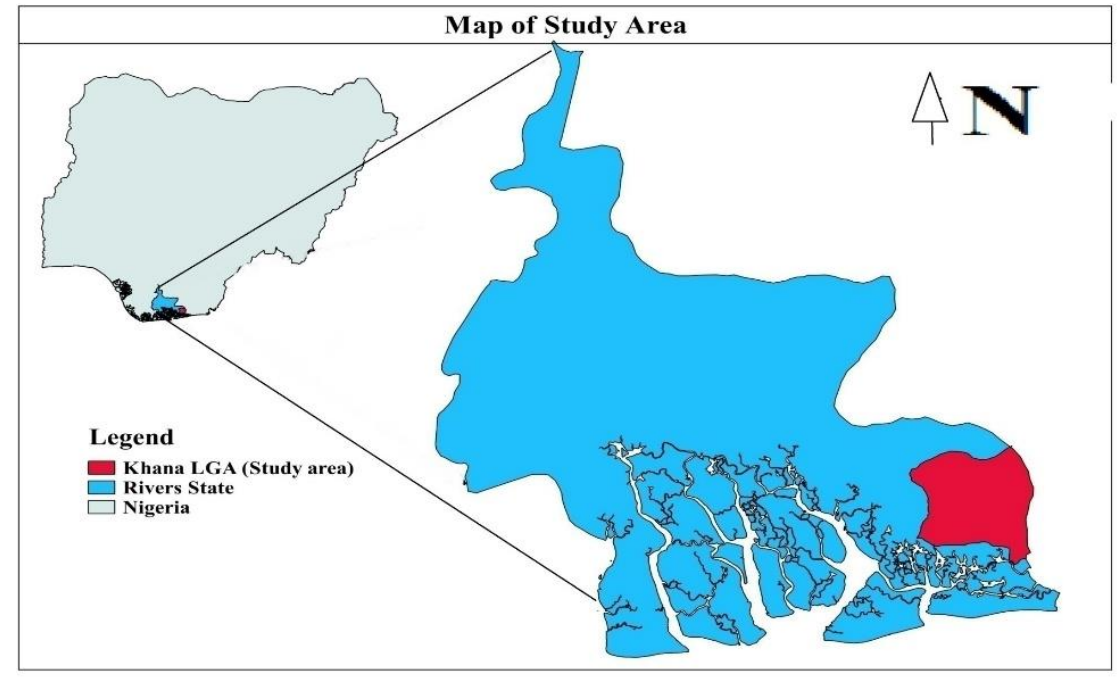

Figure 1: Map of study area. Source (author)

\subsection{Sample Area}

Selected areas (land use types) for sampling in the study area served as reference points during image classification and were reconnoitered using roads and footpaths for easy access. Five (5) dominant land-use types (Residential land, Fallow-land, Cropland, Forested land, and Oil palm plantation) were identified and assessed during reconnaissance survey.

Three secondary forested areas selected at random in the study area are over thirty years old. Land cover of these sites are densely populated with shrubs, trees, and grasses. Their location and geographical coordinates are; Baen (Longitude $4^{0} 37^{\prime} 8.26^{\prime \prime} \mathrm{N}$ and Latitude $7^{0} 28^{\prime} 17^{\prime \prime} \mathrm{E}$ ), Pue (Longitude $4^{0} 40^{\prime} 22^{\prime \prime} \mathrm{N}$ and Latitude $7^{0} 21^{\prime} 13^{\prime \prime} \mathrm{E}$ ), and Kor (Longitude $4^{0} 40^{\prime} 22^{\prime \prime} \mathrm{N}$ and Latitude $7^{0}$ $\left.21^{\prime} 13^{\prime \prime} \mathrm{E}\right)$. Three sites under continuous cassava cultivation for over 3 years were identified and selected at random in the study area. Their location and geographical coordinates are; Taabaa (Longitude $4^{0} 43^{\prime} 12.7^{\prime \prime} \mathrm{N}$ and Latitude $7^{0} 25^{\prime} 20.93^{\prime \prime} \mathrm{E}$ ), Kono (Longitude $4^{0} 36^{\prime} 18.10^{\prime \prime} \mathrm{N}$ and Latitude $7^{0} 30^{\prime} 7.09^{\prime}$ 'E), and Nyokuru (Longitude $4^{0} 43^{\prime} 47.53^{\prime \prime} \mathrm{N}$ and Latitude $7^{0} 27^{\prime} 8.18^{\prime \prime} \mathrm{E}$ ). 
The fallow sites selected have been under fallow for 2 years. The sites were identified and selected at random in the study area. Their location and geographical coordinates are; Bori (Longitude $4^{0} 40^{\prime} 4.97^{\prime \prime} \mathrm{N}$ and Latitude $7^{0} 22^{\prime} 25.29^{\prime \prime}$ 'E), Sii (Longitude $4^{0}$ $36^{\prime} 1.19^{\prime \prime} \mathrm{N}$ and Latitude $7^{0} 24^{\prime} 56.90^{\prime \prime} \mathrm{E}$ ), and Eeke (Longitude $4^{0} 36^{\prime} 1^{\prime \prime} \mathrm{N}$ and Latitude $7^{0} 25^{\prime} 20.93^{\prime \prime}$ 'E). Three residential areas were selected and identified at random in the study area. Their location and geographical coordinates are; Zaakpon (Longitude $4^{0}$ $38^{\prime} 52.36^{\prime \prime} \mathrm{N}$ and Latitude $7^{0} 23^{\prime} 4.35^{\prime \prime} \mathrm{E}$ ), Uegwere-Boue (Longitude $4^{0} 39^{\prime} 12.81^{\prime \prime} \mathrm{N}$ and Latitude $7^{0} 21^{\prime} 48.87^{\prime \prime}$ 'E), and Okwale (Longitude $4^{0} 47^{\prime} 38.96^{\prime \prime} \mathrm{N}$ and Latitude $7^{0} 23^{\prime} 27.97^{\prime} \mathrm{E}$ ). Three Oil palm plantation sites were also selected and identified at random in the study area. Their location and geographical coordinates are; Zor-Sogho (Longitude $4^{0} 45^{\prime} 5.80^{\prime \prime} \mathrm{N}$ and Latitude $7^{0}$ $22^{\prime} 52.99^{\prime \prime}$ 'E), Opuoko (Longitude $4^{0} 41^{\prime} 28.32^{\prime \prime} \mathrm{N}$ and Latitude $7^{0} 30^{\prime} 7.09^{\prime \prime} \mathrm{E}$ ), and Kani-babbe (Longitude $4^{0} 47^{\prime} 38.96^{\prime \prime} \mathrm{N}$ and Latitude $7^{0} 23^{\prime} 27.97^{\prime \prime}$ 'E).

\subsection{Land use classification methodology}

This research involved the integration of remote sensing techniques with a GIS framework to get information on the area under study using a Supervised classification system (PC-based image processing and analysis) in ArcGIS 10.1 software. Land use changes were assessed in terms of rate, trend, magnitude of change and the extent of the selected land uses to develop final output analysis and classified maps. Maximum likelihood classification was adopted for the study because the distribution of pixels in each class training areas is Gaussian. A probability value for each pixel belonging to each class is calculated and then the pixel is assigned to the class with the highest probability value. It is one of the most commonly used algorithms [6].

\subsection{Data Sources and Characteristics}

The research made use of both spatial data and administrative maps. Field survey references were used as a guide during processing and land use classification for data accuracy assessment. The spatial data include LANDSAT imageries and administrative maps. Sources of the study data are presented in Table 1.

Table 1: Data Sources

\begin{tabular}{llllll}
\hline Source & Satellites & Year & Sensor & $\begin{array}{l}\text { Spatial } \\
\text { Resolution }\end{array}$ & $\begin{array}{l}\text { Colour } \\
\text { Composite }\end{array}$ \\
\hline www.earthexplorer.usgs.gov & Landsat 8 & 2018 & OLI TIRS & $30 \mathrm{~m}$ & Band 7,5,3 \\
www.earthexplorer.usgs.gov & Landsat 7 & 2000 & TM & $30 \mathrm{~m}$ & Band 7,5,3 \\
www.earthexplorer.usgs.gov & Landsat 5 & 1987 & TM & $30 \mathrm{~m}$ & Band 7,5,3 \\
\hline
\end{tabular}

The dates of the satellite imageries used were deliberately picked to maintain a minimum of at least 3,300 days spacing or intervals for significant changes to occur. The band combination adopted (i.e. Bands 7, $5 \& 3$ ) was chosen because the main features of interest were more pronounced in this combination for easy identification and classification of signatures.

\subsection{Description of Land Use/ Classification Scheme}

The following land use and land cover classes summarized in Table 2 represent the major land use systems within the study area. These land use classes were used to classify the reflectance from the satellite imageries as they seem to be in different bands.

Table 2: Land use classification scheme

S/no. Class Description Study area reference points (Land use )

$1 \quad$ Forested

Forested land includes seasonally flooded Forest land 1, 2, \& 3 bottom land, mangrove swamps, shrub swamps, and wooded swamps including those areas that are ever-green with high density of trees and shrubs. 
$2 \quad$ Settlement area
Parcels of land developed for dwelling purpose (residential areas), commercial, markets, schools, banks, roads, etc. And other urban areas with human activities.

Agricultural lands (Cultivated lands, oil palm plantation) and other vegetation classes. Open areas tampered by human activities, Open areas for recreation and leisure purposes with very light vegetation.

Areas covered by open water such as river, Water bodies ponds, lagoons, water-logged wet lands. etc
Residential land 1, 2, \& 3

Oil palm plantation1, 2\&3; Fallow land 1, 2, \&3; Cultivated land $1,2, \& 3$.

\section{RESULTS AND DISCUSSION}

\subsection{Land Use and Land Cover Changes}

The total coverage of Khana area is about $575 \mathrm{~km}^{2}$ and its topography consists of nearly level land with gentle and undulating slopes intersected by shallow valleys that carry water intermittently and is characterized generally by sand to sandy-loam soil texture. Land use classification images of Khana area for the years 1987, 2000, and 2018 are presented in Figures 2, 3 and 4 respectively. Results from the total land coverage of the study area and each specific land use / land cover classified for the year 1987, 2000, and 2018 are presented in Table 3. Settlement (built up) area increased from approximately $60 \mathrm{Km}^{2}$ in 1987 to $67 \mathrm{Km}^{2}$ in 2000 and $377 \mathrm{Km}^{2}$ in 2018 with a corresponding progressive change in percentage of the entire area from $10 \%$ to $12 \%$ to $66 \%$ respectively. The cultivated land use type which comprises of crop land, oil palm plantations and fallow lands increased from 208 $\mathrm{Km}^{2}$ in 1987 to $447 \mathrm{Km}^{2}$ in 2000 , but reduced to $128 \mathrm{Km}^{2}$ in 2018 . The highest area covered by Forest land use was recorded in 1987 with about $296 \mathrm{Km}^{2}$ compared to $67 \mathrm{Km}^{2}$ in 2000 and $68 \mathrm{Km}^{2}$ in 2018.

Table 3 Trend in Land use of Khana Area between 1987 and 2018

\begin{tabular}{|c|c|c|c|c|c|c|c|c|}
\hline \multirow[b]{2}{*}{ Land use classes } & \multicolumn{2}{|c|}{ Extent 1987} & \multicolumn{2}{|c|}{ Extent 2000} & \multicolumn{2}{|c|}{ Extent 2018} & \multirow{2}{*}{$\begin{array}{l}\text { Magnitude of } \\
\text { change within 31yrs } \\
\left(\mathrm{Km}^{2}\right)\end{array}$} & \multirow[t]{2}{*}{$\begin{array}{l}\text { Percentage } \\
\text { Change }(\%)\end{array}$} \\
\hline & $\mathbf{K m}^{2}$ & $\%$ & $\mathrm{Km}^{2}$ & $\%$ & $\mathrm{Km}^{2}$ & $\%$ & & \\
\hline Forest & 296 & 51 & 67 & 12 & 68 & 12 & -228 & 77 \\
\hline Cultivated land & 208 & 36 & 447 & 78 & 128 & 22 & -80 & 38.46 \\
\hline Water & 4 & 1 & 1 & 0.2 & 2 & 0.4 & -2 & 0.5 \\
\hline Settlement (Built up area) & 60 & 10 & 67 & 12 & 377 & 66 & +317 & 84 \\
\hline Total & 575 & 100 & 575 & 100 & 575 & 100 & & \\
\hline
\end{tabular}

$=$ Decrease $;+$ =Increase. 


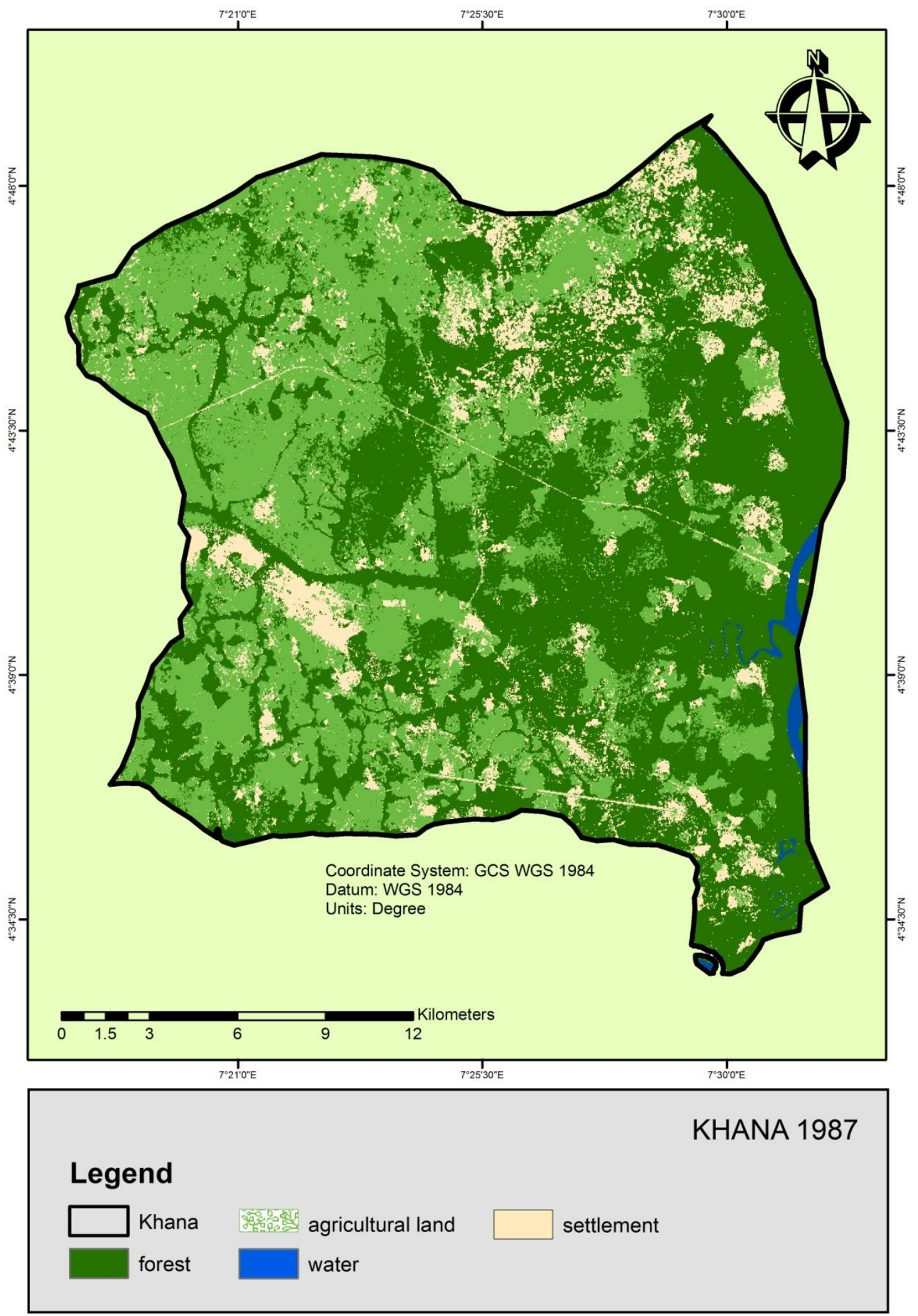

Figure 2: land use map of Khana in 1987. Source (Author) 


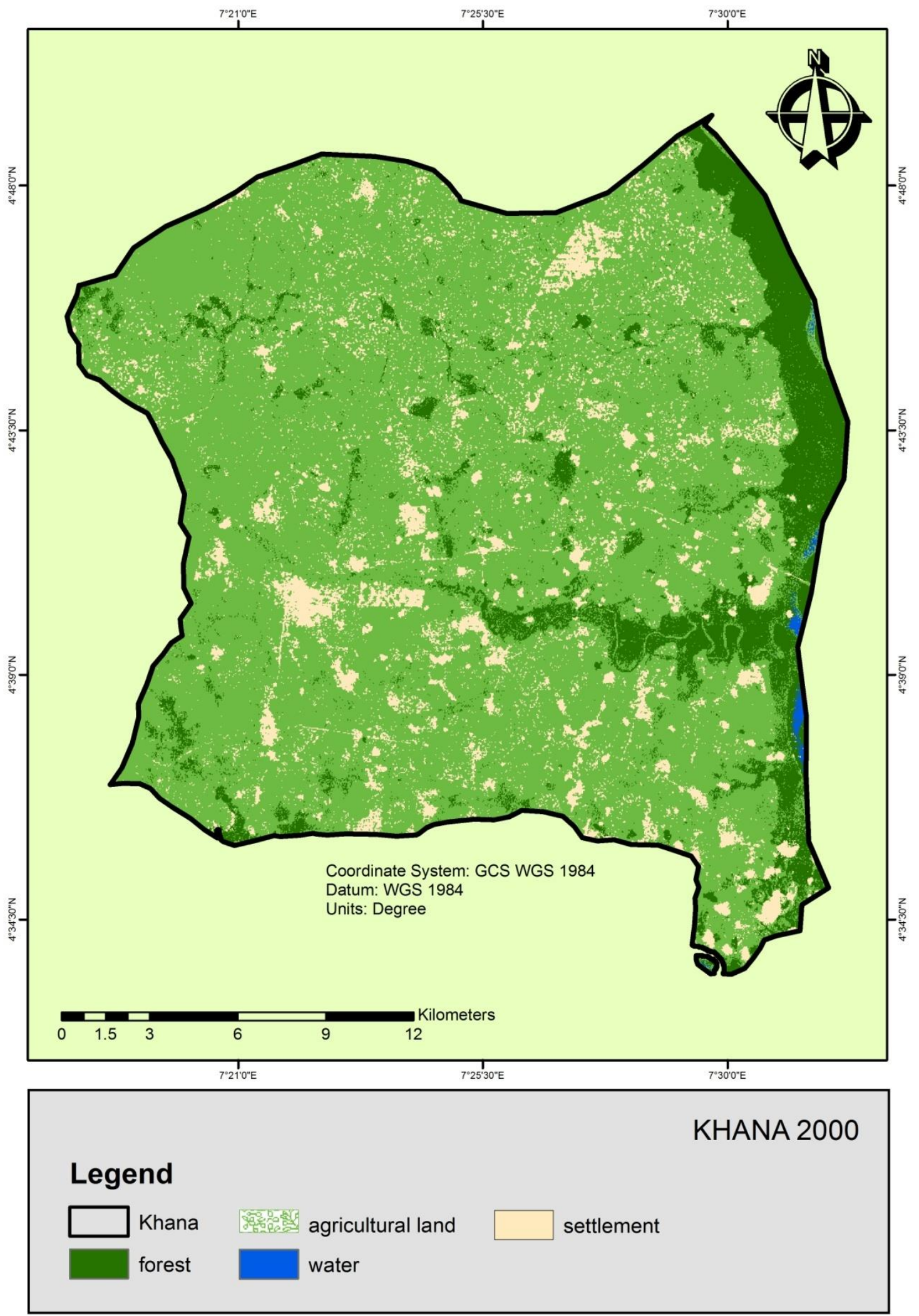

Figure 3: land use map of Khana in 2000. Source (Author) 


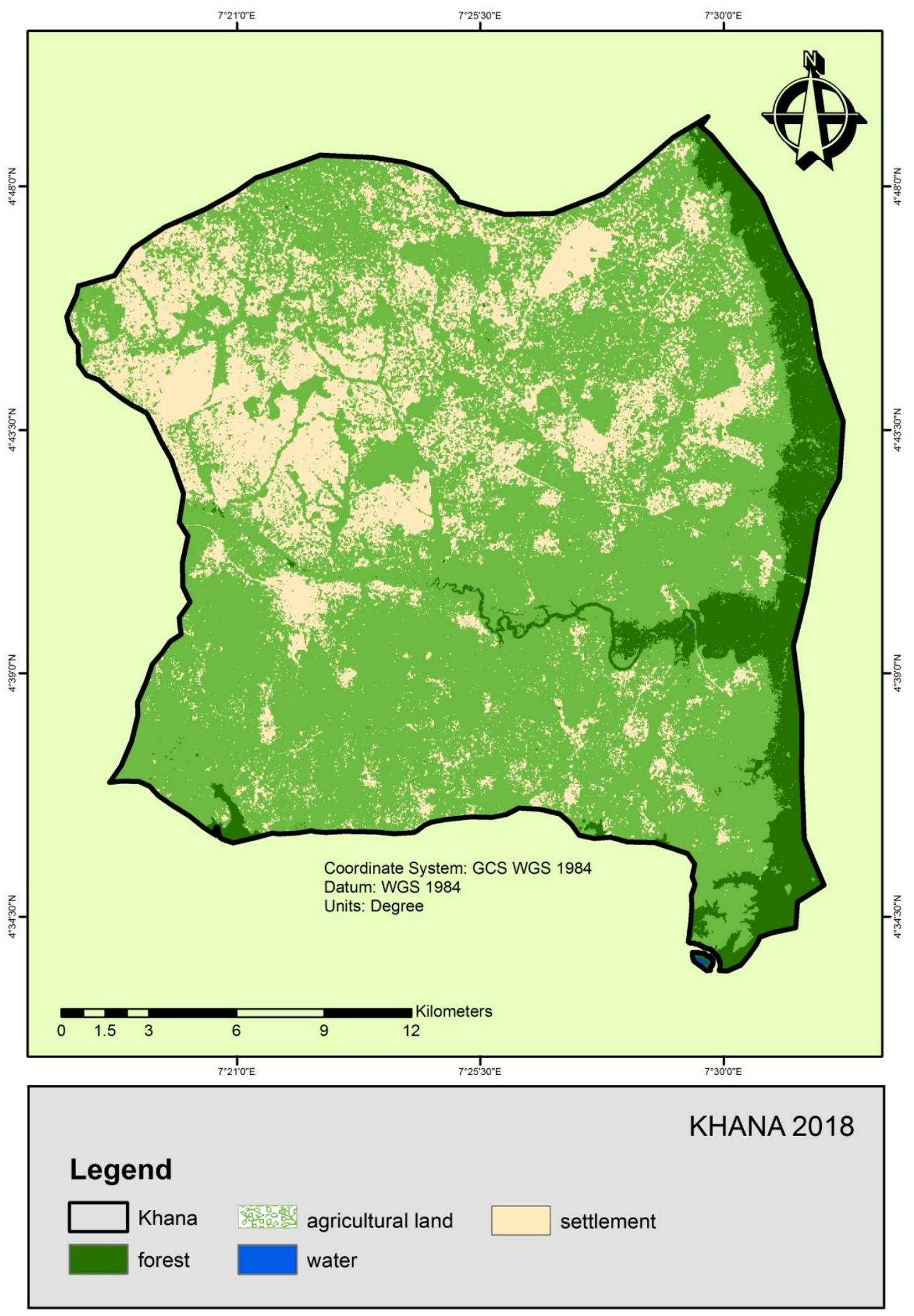

Figure 4: land use map of Khana in 2018. Source (Author)

The change in land use and land cover over the past two decades showed an accelerated growth rate especially in Urban/settlement areas with about $84 \%$ increase and an alarming reduction rate in forested areas of study area of about $77 \%$ between year 1987 and 2018. This result indicates population increase and development patterns which expanded into areas once used for both forest and agricultural purposes are now used mainly for building settlements and commercial centers. The highest area covered by forest land use recorded in 1987 with about $296 \mathrm{Km}^{2}$ compared to $68 \mathrm{Km}^{2}$ in 2018 showed how much urban area 
expansion has affected the environment. Both agricultural land and forest resources as well as its habitat diminished and has affected the ecosystem and food security in the area. This has increased the cost of living and has affected income of farmers in the area since less land are now cultivated. Severe deforestation in forested areas, reduction of farmlands, increased cost of living, and soil erosion. These are the major challenges faced presently as a result of this land use change in the study area. If deliberate policies are not made and implemented, the remaining natural habitat could be lost by the year 2050 .

\section{CONCLUSION}

The study revealed that land use and land cover changed over the past three decades especially in Urban/settlement areas with about $84 \%$ increase and an alarming reduction rate of about $77 \%$ in forested areas between year 1987 and 2018 as a result of population increase. Data generated from the land use change detection should encourage proper land use policy development in the area for both urban and agricultural development so as to increase yield in crop production and enhance optimum land utilization. Cultivable lands should not be used for building settlements only and Forested land should be protected from deforestation and wildlife extinction. This will decrease the rate at which Forest areas reduces and also maintain its nutrient status. Also since land use changes with time and for various reasons, the acquisition and updating of land use maps is very important. Thus a land use data base is very important for the study area. This is to enable future projections to be made and scenarios developed considering the trends in land use change.

\section{REFERENCES}

1. A. De Sherbinin. (2002). "Land use and Land cover change". In: ACIESIN Thermatic Guide. Palisades, NY: centre of international Earth Science information network of Columbia University.

2. J.R. Anderson, E.E. Hardy, J.T. Roach, R.E. Witmer. (2001). "A land use and land cover classification system for use with remote sensor data." Geological Survey Professional Paper 964 and a revision of the land use classification system as presented in U.S Geological Survey Circular 671.

3. R. Chakir, and O. Parent. (2008). "Determinants of land use changes. A spatial multinominal probit approach.” In: Papers in Regional science, volume 88, No. 2, June 2009.

4. A. Singh. (1989). "Review Article-Digital change detection techniques using remotely-sensed data". International Journal of Remote Sensing, 10, pp. 989-1003.

5. U.O Ufot, O.B. Iren, and C.U. Chikere. (2016). "Effects of landuse on soil physical and chemical properties in Akokwa area of Imo state, Nigeria”. Int. J. Life. Sci. Scienti. Res., 2(3): -273-27. 2016. https://doi.org/10.21276/ijlssr.2016.2.3.14

6. T.M Lillesand, R.W. Kiefer, J.W. Chipman. (2008). "Remote sensing and image interpretation". 6 ${ }^{\text {th }}$ ed. New York, NY: John Wiley \& Sons, 756 p.

\section{ACKNOWLEDGMENT}

Special thanks goes to Dr O.J. Kamalu and Dr. Chima Wokocha for their discussions and contributions made during the course of this study. Also grateful to lecturers in the Department of Crop and Soil Science, University of Port Harcourt for their encouragement and support. My sincere appreciation goes to my brother, Mr. Mike Needam who supported me financially, and my mother, Mrs. Lekae Needam, Mr. Matthew Needam, and Uncle Leedee for their moral support. All thanks go to God for His grace and Mercy. 